\title{
Borane-osmium cluster chemistry
}

\author{
S. G. Shore \\ Department of Chemistry, The Ohio State University, Columbus, Ohio 43210
}

\begin{abstract}
Triosmium carbonyl borylidyne clusters $(\mu-\mathrm{H})_{3} \mathrm{Os}_{3}(\mathrm{CO})_{9}\left(\mu_{3}-\mathrm{BCO}\right), \mathbf{L}(\mu-\mathrm{H})_{3^{-}}$ $\mathrm{Os}_{3}(\mathrm{CO})_{8}\left(\mathrm{PPh}_{3}\right)\left(\mu_{3}-\mathrm{BCO}\right)$, $\mathrm{I}$, and the boroxin supported triosmium oxomethylidyne cluster system $\left[(\mu-\mathrm{H})_{3} \mathrm{Os}_{3}(\mathrm{CO})_{9}\left(\mu_{3}-\mathrm{CO}\right)\right]_{3}\left[\mathrm{~B}_{3} \mathrm{O}_{3}\right]$, $\mathrm{II}$, are produced in the hydroboration of the unsaturated clusters $(\mu-\mathrm{H})_{2} \mathrm{Os}_{3}(\mathrm{CO})_{10}$, and $(\mu-\mathrm{H})_{2} \mathrm{Os}_{3}(\mathrm{CO})_{9}\left(\mathrm{PPh}_{3}\right)$. Reactions of these complexes are described. Investigations include kinetic studies of the displacement of the unique carbonyl in I and II by $\mathrm{PMe}_{3}$; the conversion of I and II, into boron containing analogues of vinylidene and alkyne clusters through reactions with $\mathrm{THFBH}_{3}$ and boron halides; and the thermal conversion of $I$ into osmaboride clusters. Reactions of III with boron halides to form triosmium chloro and bromomethylidene clusters are described. Friedel-Crafts type reactions of $\mathbf{I I I}$ in the presence of $\mathrm{BF}_{3}$ to form triosmium phenyl, pentaboranyl and icosacarboranylmethylidyne clusters are also discussed.
\end{abstract}

\section{INTRODUCTION}

While hydroboration of unsaturated organic compounds by boranes is a well established synthetic tool in organic chemistry (1), the hydroboration of organometallic complexes containing unsaturated metalmetal (2) or metal-ligand (3) bonds is relatively recent. In this laboratory we have shown (2) that two different cluster systems can be produced by means of appropriate choice of reaction conditions for the hydroboration of the unsaturated cluster $\left(\mu-\mathrm{H}_{2}\right)_{2} \mathrm{Os}_{3}(\mathrm{CO})_{10}$, a triangular molecule in which two of the osmium atoms are doubly hydrogen bridged. This molecule is electron deficient. It contains 46 instead of the 48 valence electrons required for an electron precise triangular molecule of the iron sub-group.

\section{HYDROBORATION REACTIONS}

The carbonyl borylidyne cluster $\left(\mu-\mathrm{H}_{3} \mathrm{Os}_{3}(\mathrm{CO})_{9}\left(\mu_{3}-\mathrm{BCO}\right), \mathbf{L}\right.$, is produced $(2 \mathrm{a}, \mathrm{c})$ in the following hydroboration reaction, Reaction (1). It is an analogue of the ketenylidene cluster $(\mu-\mathrm{H})_{2} \mathrm{Os}_{3}(\mathrm{CO})_{9}\left(\mu_{3}-\mathrm{CCO}\right)$.

$$
(\mu-\mathrm{H})_{2} \mathrm{Os}_{3}(\mathrm{CO})_{10}+1 / 2 \mathrm{~B}_{2} \mathrm{H}_{6} \stackrel{\mathrm{CH}_{2} \mathrm{Cl}_{2} / \mathrm{Me}_{2} \mathrm{O}}{\longrightarrow}(\mu-\mathrm{H})_{3} \mathrm{Os}_{3}(\mathrm{CO})_{9}\left(\mu_{3}-\mathrm{BCO}\right)+\mathrm{H}_{2}
$$

The molecular structure of I (Fig. 1a) is tetrahedral, in which the $\mathrm{Os}_{3}$ face is capped by a nearly linear $\mathrm{BCO}$ unit that is tilted $6.4^{\circ}$ from perpendicularity with respect to the $\mathrm{Os}_{3}$ triangle. In the formation of $\mathbf{I}$, a $\mathrm{BH}_{3}$ unit adds to the $\mathrm{Os}_{3}$ triangle, transfers hydrogen to it and effectively inserts into the OsCO bond in the process of capping the $\mathrm{Os}_{3}$ unit. The B-C distance is 1.469 (15) $\AA$. A related carbonyl borylidyne $(\mu-\mathrm{H})_{3} \mathrm{Os}_{3}(\mathrm{CO})_{8}\left(\mathrm{PPh}_{3}\right)\left(\mu_{3}-\mathrm{BCO}\right)$, II, is obtained (2c) from the hydroboration of $\left(\mu-\mathrm{H}_{2} \mathrm{Os}_{3}(\mathrm{CO})_{9}\left(\mathrm{PPh}_{3}\right)\right.$; it is structurally similar to I (Fig. Ib).

On the other hand the hydroboration of $(\mu-\mathrm{H})_{2} \mathrm{Os}_{3}(\mathrm{CO})_{10}$ by THFBH $\mathrm{TH}_{3} \mathrm{CH}_{2} \mathrm{Cl}_{2}$ solution with the ratio THF: $\mathrm{B}_{2} \mathrm{H}_{6}>2: 1$ produces the boroxin supported triosmium oxomethylidyne cluster system $\left[(\mu-\mathrm{H})_{3} \mathrm{Os}_{3}(\mathrm{CO})_{9}\left(\mu_{3}-\mathrm{CO}\right)\right]_{3}\left[\mathrm{~B}_{3} \mathrm{O}_{3}\right], \mathrm{III},(2 \mathrm{~b}, \mathrm{c})$ (Reaction (2)). Its structure ( Fig. 2a) consists of three

$$
(\mu-\mathrm{H})_{2} \mathrm{Os}_{3}(\mathrm{CO})_{10}+\mathrm{THFBH}_{3} \stackrel{\mathrm{CH}_{2} \mathrm{Cl}_{2} / \mathrm{THF}}{\longrightarrow}\left[(\mu-\mathrm{H})_{3} \mathrm{Os}_{3}(\mathrm{CO})_{9}\left(\mu_{3}-\mathrm{CO}\right)\right]_{3}\left[\mathrm{~B}_{3} \mathrm{O}_{3}\right]+\mathrm{C}_{4} \mathrm{H}_{10}
$$

oxomethylidyne cluster units, $\left.(\mu-\mathrm{H})_{3} \mathrm{Os}_{3}(\mathrm{CO})_{9}\right)\left(\mu_{3}-\mathrm{CO}\right)$, linked to a boroxin $\left(\mathrm{B}_{3} \mathrm{O}_{3}\right)$ ring via oxygen 


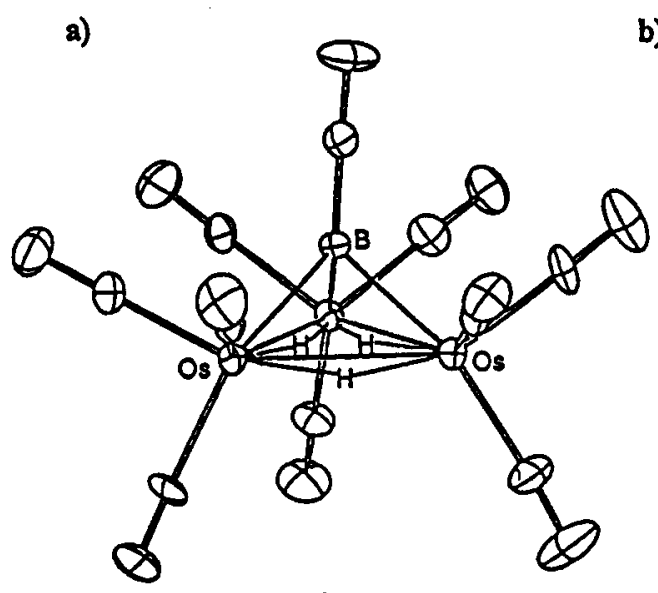

b)

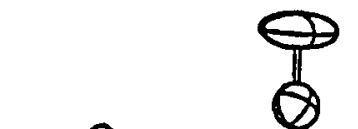

)
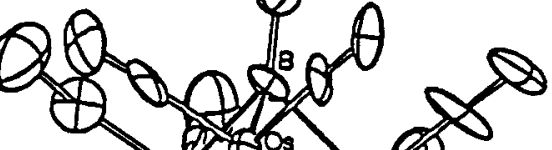

Fig. 1. a) Molecular structure of $(\mu-\mathrm{H})_{3} \mathrm{Os}_{3}(\mathrm{CO})_{9}\left(\mu_{3}-\mathrm{BCO}\right)$, $\mathbf{L}$

b) Molecular structure of $(\mu-\mathrm{H})_{3} \mathrm{Os}_{3}(\mathrm{CO})_{8}\left(\mathrm{PPh}_{3}\right)\left(\mu_{3}-\mathrm{BCO}\right)$, II

bridges. In the formation of this complex it appears that one hydrogen of the $\mathrm{THFBH}_{3}$ is transferred to the $\mathrm{Os}_{3}$ triangle whereas the resulting $\mathrm{BH}_{2} \mathrm{THF}$ unit binds to a terminal carbonyl causing it to move to a capping position over the $\mathrm{Os}_{3}$ unit. Subsequent transfer of the remaining $\mathrm{BH}$ hydrogens of $\mathrm{BH}_{2} \mathrm{THF}$ to the THF ring results in the formation of $\mathrm{C}_{4} \mathrm{H}_{10}$ and a BO unit linked to the triosmium carbonyl methylidyne via an oxygen bridge. Trimerization of these BO units results in the boroxin supported cluster system II. Experimental evidence and details for schemes for the proposed reaction pathways for the formation of I and II are described elsewhere (2c).

Hydroboration of $(\mu-\mathrm{H})_{2} \mathrm{Os}_{3}(\mathrm{CO})_{10}$ by catechol borane gives the oxomethylidyne cluster $(\mu-\mathrm{H})_{3}$ $\mathrm{Os}_{3}(\mathrm{CO})_{9}\left(\mu_{3}-\mathrm{COBO}_{2} \mathrm{C}_{6} \mathrm{H}_{4}\right), \mathbf{I V}$, (Reaction (3)). Its proposed structure (Fig. 2b) is based upon spectro-

$$
(\mu-\mathrm{H})_{2} \mathrm{Os}_{3}(\mathrm{CO})_{10}+\mathrm{C}_{6} \mathrm{H}_{4} \mathrm{O}_{2} \mathrm{BH} \longrightarrow(\mu-\mathrm{H})_{3} \mathrm{Os}_{3}(\mathrm{CO})_{9}\left(\mu_{3}-\mathrm{COBO}_{2} \mathrm{C}_{6} \mathrm{H}_{4}\right)
$$

scopic data (MS, IR, ' $\mathrm{H},{ }^{11} \mathrm{~B}$, and ${ }^{13} \mathrm{C}$ NMR), elemental analysis, and its derivative chemistry (2c).

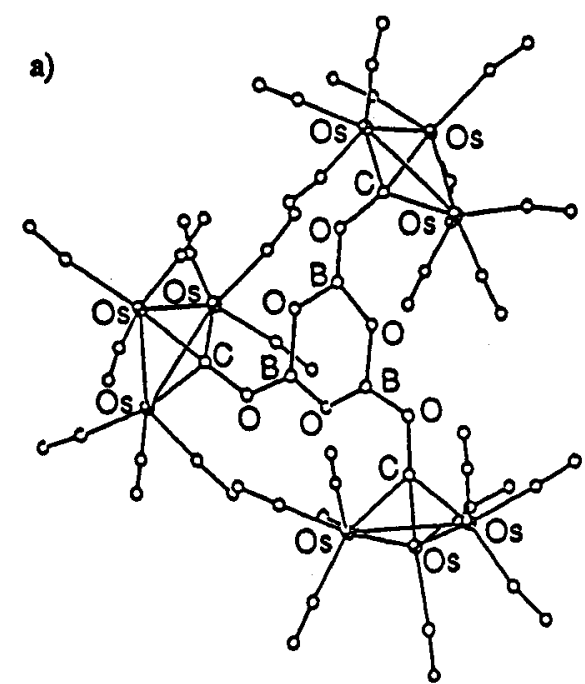

b)

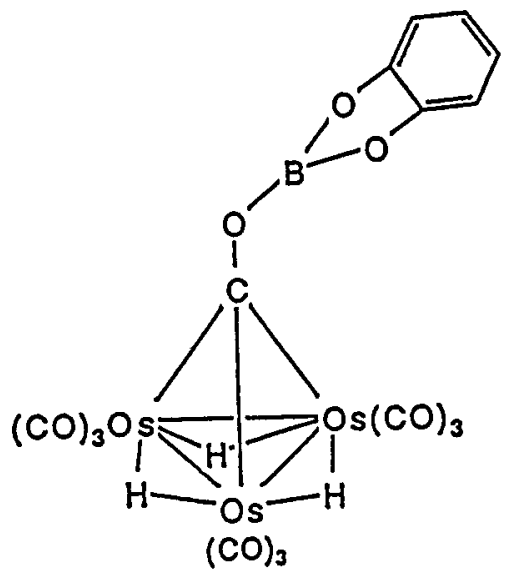

Figure 2. a) Molecular structure of $\left[\left(\mu-\mathrm{H}_{3}\right)_{3} \mathrm{~s}_{3}(\mathrm{CO})_{9}\left(\mu_{3}-\mathrm{CO}\right)\right]_{3}\left[\mathrm{~B}_{3} \mathrm{O}_{3}\right]$, III.

b) Proposed molecular structure of $(\mu-\mathrm{H})_{3} \mathrm{Os}_{3}(\mathrm{CO})_{9}\left(\mu_{3}-\mathrm{COBO}_{2} \mathrm{C}_{6} \mathrm{H}_{4}\right)$, IV. 


\section{DISPLACEMENT OF CARBON MONOXIDE FROM CARBONYL BORYLIDYNES}

Complexes I and II are remarkable molecules. Unlike many transition metal carbonyl clusters, they are not fluxional on the NMR time-scale up to their decomposition temperatures, $c a 90^{\circ} \mathrm{C}$ $(2 \mathrm{a}, \mathrm{c}, 4)$. Furthermore, no detectable exchange of carbon monoxide gas with carbon monoxide in ${ }^{13} \mathrm{C}$ enriched I and II occurs up to $1,000 \mathrm{psi}$ and $50{ }^{\circ} \mathrm{C}$ for three days. On the other hand the carbonyl on the boron site is readily displaced by $\mathrm{PMe}_{3}$ at room temperature. In the case of $\mathrm{I}$ the carbon monoxide at the apical site is exclusively replaced by $\mathrm{PMe}_{3}$ to form $(\mu-\mathrm{H})_{3} \mathrm{Os}_{3}(\mathrm{CO})_{9}\left(\mu_{3}-\mathrm{BPMe}_{3}\right), \mathrm{V}$, at room temperature within 1 day when the molar ratio $\mathrm{PMe}_{3}: \mathrm{I}$ is $\leq 1: 1$ (Reaction 4).

$$
(\mu-\mathrm{H})_{3} \mathrm{Os}_{3}(\mathrm{CO})_{9}\left(\mu_{3}-\mathrm{BCO}\right)+\mathrm{PMe}_{3} \stackrel{\mathrm{CH}_{2} \mathrm{Cl}_{2}}{\longrightarrow}(\mu-\mathrm{H})_{3} \mathrm{Os}_{3}(\mathrm{CO})_{9}\left(\mu_{3}-\mathrm{BPMe}_{3}\right)+\mathrm{CO}
$$

The reaction of II with $\mathrm{PMe}_{3}$, however, gives a mixture of $\mathrm{V}$ and $(\mu-\mathrm{H})_{3} \mathrm{Os}_{3}(\mathrm{CO})_{8}\left(\mathrm{PPh}_{3}\right)\left(\mu_{3}-\mathrm{BPMe}\right), \mathrm{VI}$, in a ratio of 1.5:1-2.0:1 over the temperature range $15-40^{\circ} \mathrm{C}$. These products are formed in parallel, concurrent reactions and the products are produced in a constant ratio as the reaction progresses (Reactions $5 a$ and $5 b)(4)$.

$$
\begin{gathered}
(\mu-\mathrm{H})_{3} \mathrm{Os}_{3}(\mathrm{CO})_{8}\left(\mathrm{PPh}_{3}\right)\left(\mu_{3}-\mathrm{BCO}\right)+\mathrm{PMe}_{3} \stackrel{\mathrm{CH}_{2} \mathrm{Cl}_{2}}{\longrightarrow}(\mu-\mathrm{H})_{3} \mathrm{Os}_{3}(\mathrm{CO})_{8}\left(\mathrm{PPh}_{3}\right)\left(\mu_{3}-\mathrm{BPMe}_{3}\right)+\mathrm{CO} \\
\left(\mu-\mathrm{H}_{3} \mathrm{Os}_{3}(\mathrm{CO})_{8}\left(\mathrm{PPh}_{3}\right)\left(\mu_{3}-\mathrm{BCO}\right)+\mathrm{PMe}_{3} \stackrel{\mathrm{CH}_{2} \mathrm{Cl}_{2}}{\longrightarrow}\left(\mu-\mathrm{H}_{3} \mathrm{Os}_{3}(\mathrm{CO})_{9}\left(\mu_{3}-\mathrm{BPMe}_{3}\right)+\mathrm{PPh}_{3}\right.\right.
\end{gathered}
$$

Studies of kinetics of reactions of $\mathrm{PMe}_{3}$ with $\mathbf{I}$ and $\mathbf{I I}$ indicate that they are associative in nature, being first order in cluster and first order in $\mathrm{PMe}_{3}$. Rate constants and activation parameters are summarized in Table I. Several pathways have been considered as possible routes for substitution Reactions (4), (5a), and (5b). Since no experimental method appears to be available for preferentially labeling complexes I and II with ${ }^{13} \mathrm{CO}$, additional experimental information that might assist in choosing a mechanistic pathway is not available.

TABLE 1. Rate Constants and Activation Parameters for Reactions (4) and (5) at $293{ }^{\circ} \mathrm{K}$

\begin{tabular}{llll}
\hline Reaction & $\mathrm{k}, \mathrm{M}^{-1} \mathrm{~s}^{-1} \times 10^{3}$ & $\Delta \mathrm{H}^{\ddagger}, \mathrm{kcal} / \mathrm{mol}$ & $\Delta \mathrm{S}^{\ddagger}, \mathrm{cal} / \mathrm{mol}-\mathrm{deg}$ \\
\hline$(3)$ & $2.56 \pm 0.17$ & $18.0 \pm 0.8$ & $-8.8 \pm 2.6$ \\
$(4 \mathrm{a})$ & $2.27 \pm 0.05$ & $19.1 \pm 0.8$ & $-5.3 \pm 2.6$ \\
$(4 \mathrm{~b})$ & $1.42 \pm 0.03$ & $17.8 \pm 0.6$ & $-11.0 \pm 2.0$ \\
\hline
\end{tabular}

One pathway that has been considered and rejected involves addition of $\mathrm{PMe}_{3}$ to a basal osmium atom followed by migration of the $\mathrm{PMe}_{3}$ to the boron atom, displacing the apical $\mathrm{CO}$. This pathway is considered to be unlikely in the present case, since the enthalpys of activation for Reactions (4), (5a), and (5b) are not significantly different. The position of $\mathrm{PPh}_{3}$ at an axial position on an osmium atom (Figure 1b) is expected to significantly hinder the approach of $\mathrm{PMe}_{3}$ with consequent increase in the enthalpy's of activation for Reactions (5a) and (5b) compared to that for Reaction (4).

A second pathway that has been considered and rejected involves initial attack of the $\mathrm{PMe}_{3}$ at the carbon atom of the carbonyl attached to boron to form an adduct followed by a concerted exchange between $\mathrm{CO}$ and $\mathrm{PMe}_{3}$. One difficulty with this proposal resides in the substantial steric hindrance caused by the arrangement of six of the nine carbonyls that are disposed upward in the direction of the apical boron (Figures $\mathrm{la}$ and $\mathrm{lb}$ ). Furthermore, the low entropy of activation observed compared to that observed for mononuclear substitution reactions with a transition state of higher coordination number than that of the ground state ( $\mathrm{ca}-25 \mathrm{cal} / \mathrm{mol}-\mathrm{deg}$ ) suggests that there is appreciable rearrangement in the structure of the activated complex in the current system (5). 
A reaction pathway that we favor involves a cluster-opening step by adding $\mathrm{PMe}_{3}$ to $\mathrm{I}$ or $\mathrm{II}$ to form an intermediate with a "butterfly" structure followed by a subsequent cluster reclosing step to eject $\mathrm{CO}$ with the formation of $\mathbf{V}$ or VI If $\mathrm{PPh}_{3}$ is eliminated in the cluster reclosing step, VI is formed. Scheme 1 represents these pathways for the formation of $\mathrm{V}$ and $\mathrm{VI}$ in the reaction of II with $\mathrm{PMe}_{3}$ (Reactions (5a) and (5b)). In this scheme $\mathrm{PMe}_{3}$ adds to the cluster to form one of two possible isomeric "butterfly" intermediates. In the reformation of the $\mathrm{Os}_{3} \mathrm{~B}$ tetrahedral core either $\mathrm{CO}$ or $\mathrm{PPh}_{3}$ is eliminated to yield respectively either $\mathbf{V}$ or VL Statistically it is twice as favorable to eliminate CO than $\mathrm{PPh}_{3}$ thereby accounting for a ratio of V:VI that approaches 2:1 with increasing temperature. Route (b) shown in this scheme is also applicable to the formation $\mathbf{V}$ in the reaction of $\mathbf{I}$ with $\mathrm{PMe}_{3}$.

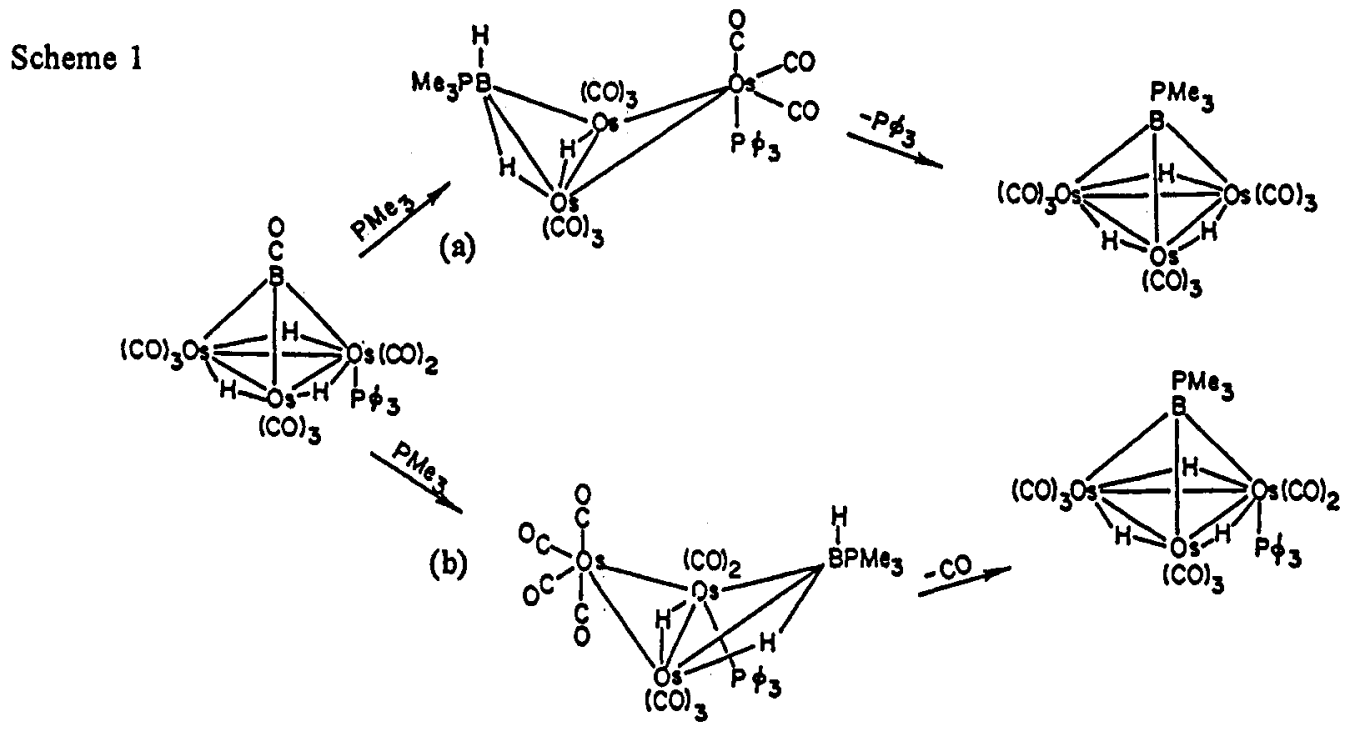

A reaction pathway with an intermediate of "butterfly geometry" has also been proposed in the CO substitution reaction of $\mathrm{Ir}_{4}(\mathrm{CO})_{12}$ by trialkyl phosphines $(6)$. This reaction pathway appears to be operative in several systems in which intermediates with open structures have been isolated or detected (7).

\section{REACTIONS OF I WITH LEWIS ACIDS}

\section{A. Vinylidene cluster analogues}

1. Reaction of I with THFBH $_{3}$. The unique carbonyl in I is reduced to a methylene group by $\mathrm{THFBH}_{3}$ to form $(\mu-\mathrm{H})_{3} \mathrm{Os}_{3}(\mathrm{CO})_{9}\left(\mu_{3}-\hat{\eta}^{2}-\mathrm{BCH}_{2}\right)$, VII, (Reaction (6) (8a, b). Its structure (Figure 3a)

$$
(\mu-\mathrm{H})_{3} \mathrm{Os}_{3}(\mathrm{CO})_{9}\left(\mu_{3}-\mathrm{BCO}\right)+\mathrm{THFBH}_{3} \longrightarrow(\mu-\mathrm{H})_{3} \mathrm{Os}_{3}(\mathrm{CO})_{9}\left(\mu_{3}-\dot{\eta}^{2}-\mathrm{BCH}_{2}\right)+\mathrm{B}_{3} \mathrm{H}_{3} \mathrm{O}_{3}
$$

resembles that of the vinylidene cluster $(\mu-\mathrm{H})_{2} \mathrm{Os}_{3}(\mathrm{CO})_{9}\left(\mu_{3}-\eta^{2}-\mathrm{CCH}_{2}\right)(9)$. However the B-C bond is canted $60^{\circ}$ from the perpendicular with respect to the $\mathrm{Os}_{3}$ plane which is significantly larger than observed for the analogous $\mathrm{C}-\mathrm{C}$ bond in structurally characterized vinylidene clusters $\left(40-50^{\circ}\right)(10)$. The two B-H-Os bridges in the structure probably force the $\mathrm{BCH}_{2}$ unit to an extreme tilt angle compared to the vinylidene complexes. The extreme tilt angle implies that the compound could also be described as a methylenebridged complex. However, the "short" B-C distance, 1.498 (15) $\AA$, compared to observed B-C single bond distances that are ca $0.1 \AA$ longer $(11 \mathrm{a}, \mathrm{b})$ suggest partial double bond character and the relatively long Os-C distance, 2.325 (17) $\AA$, favor the vinylidene analogy.

Formation of VII is believed to occur through initial coordination of $\mathrm{BH}_{3}$ to the oxygen atom of the carbonyl to give $(\mu-\mathrm{H})_{3} \mathrm{Os}_{3}(\mathrm{CO})_{9}\left(\mu_{3}-\mathrm{BCOBH}_{3}\right)$ followed by transfer of two $\mathrm{BH}$ hydrogens to the carbon atom. Elimination of $\mathrm{H}-\mathrm{B}-\mathrm{O}$ as the boroxine trimer, $\mathrm{B}_{3} \mathrm{H}_{3} \mathrm{O}_{3}$, would then result in the formation of VII Deuterium-labeling experiments indicate that reduction of the $\mathrm{CO}$ occurs with no apparent scrambling of $\mathrm{B}-\mathrm{H}, \mathrm{C}-\mathrm{H}$, and Os-H-Os hydrogen atoms. 
2. Reaction of $/ I$ with Boron Trihalides. Boron trihalides react with $I$ to form vinylidene cluster analogues $\left(\mu-\mathrm{H}_{3} \mathrm{Os}_{3}(\mathrm{CO})_{9}\left(\mu_{3}-\mathrm{CBX}_{2}\right)(\mathrm{X}=\mathrm{Cl}, \mathrm{B}), \mathrm{VII}\right.$, in which the boron and carbon have exchanged positions (Reaction (7)) $(8 \mathrm{~b}, \mathrm{c})$. The reaction of ${ }^{10} \mathrm{BCl}_{3}$ with $\mathrm{I}$ does not involve interchange of ${ }^{10} \mathrm{~B}$ with the

$$
\begin{aligned}
& \left(\mu-\mathrm{H}_{3} \mathrm{Os}_{3}(\mathrm{CO})_{9}\left(\mu_{3}-\mathrm{BCO}\right)+\mathrm{BX}_{3} \longrightarrow(\mu-\mathrm{H})_{3} \mathrm{Os}_{3}(\mathrm{CO})_{9}\left(\mu_{3}-\mathrm{CBX}_{2}\right)+1 / 3 \mathrm{~B}_{3} \mathrm{X}_{3} \mathrm{O}_{3}\right. \\
& \quad \mathrm{X}=\mathrm{Cl}, \mathrm{Br}
\end{aligned}
$$

"B in the cluster. Therefore, the formation of VIII appears to involve intramolecular exchange of the boron and carbon atoms of I. The structure of VIII (Figure 36 ) differs from that of VII not only in that the

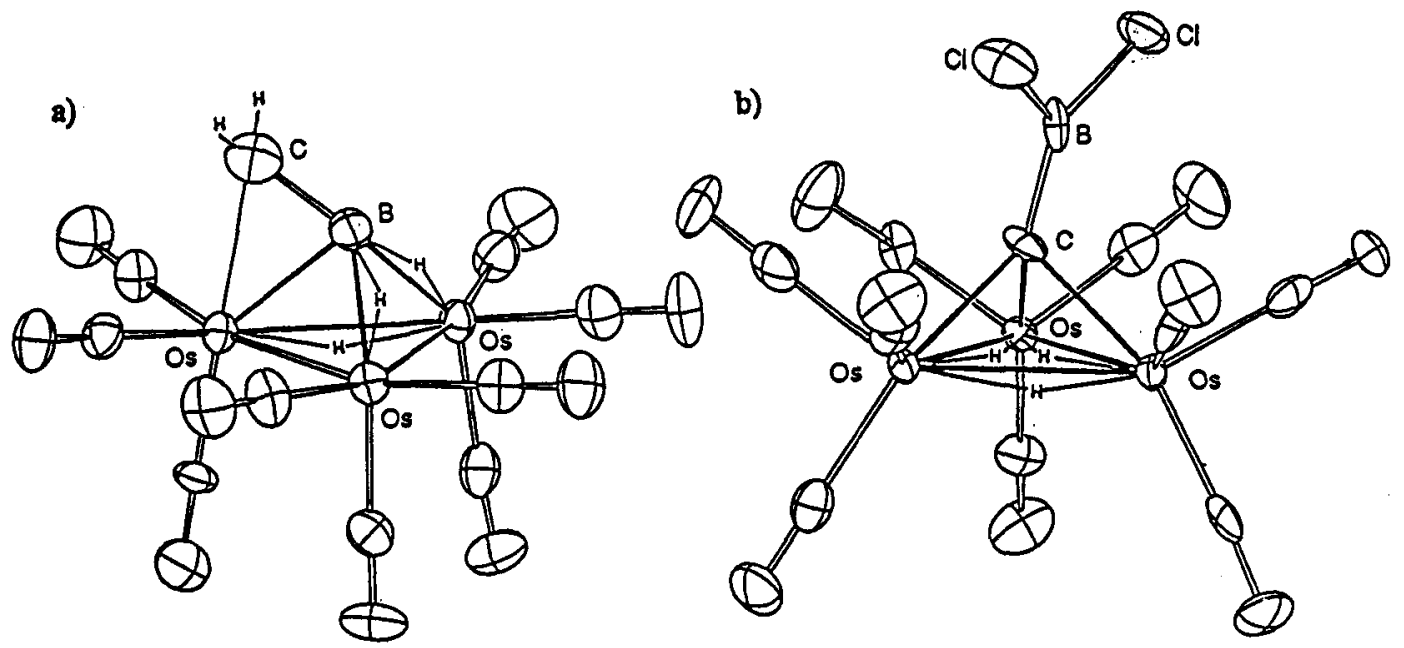

Fig. 3. a) Molecular structure of $(\mu-H)_{3} \mathrm{Os}_{3}(\mathrm{CO})_{9}\left(\mu_{3}-\eta^{2}-\mathrm{BCH}_{2}\right)$, VII.

b) Molecular structure of $(\mu-\mathrm{H})_{3} \mathrm{Os}_{3}(\mathrm{CO})_{9}\left(\mu_{3}-\mathrm{CBX}_{2}\right)(\mathrm{X}=\mathrm{Cl}, \mathrm{Br})$, VIII

carbon positions are reversed but also the C-B bond in VIII is canted only $15^{\circ}$ from perpendicularity to the $\mathrm{Os}_{3}$ plane. As in the case VII, the B-C distance 1.47 (2) $\AA$ is "short" compared to observed (11) single bond B-C distances.

Scheme 2 presents a proposed pathway by which VIII is formed. Upon interacting with the unique carbonyl oxygen, the boron trihalide is a sufficiently strong electron withdrawing agent to reduce the bond order of the carbon oxygen bond causing it to move to a bridging site. Movement of the carbonyl ligand into the $\mu_{3}$ site exposes the boron and results in successive halogen atom transfer from the reagent boron to the cluster boron. Compound VIII is produced when X-B-O is eliminated as $\mathrm{B}_{3} \mathrm{X}_{3} \mathrm{O}_{3}$, That reaction of $\mathrm{I}$ with $\mathrm{BH}_{3}$ differs from its reactions with boron trihalides is attributed (8b) to the relatively stronger Lewis acidities of the trihalides toward oxygen donors than $\mathrm{BH}_{3}(12)$.

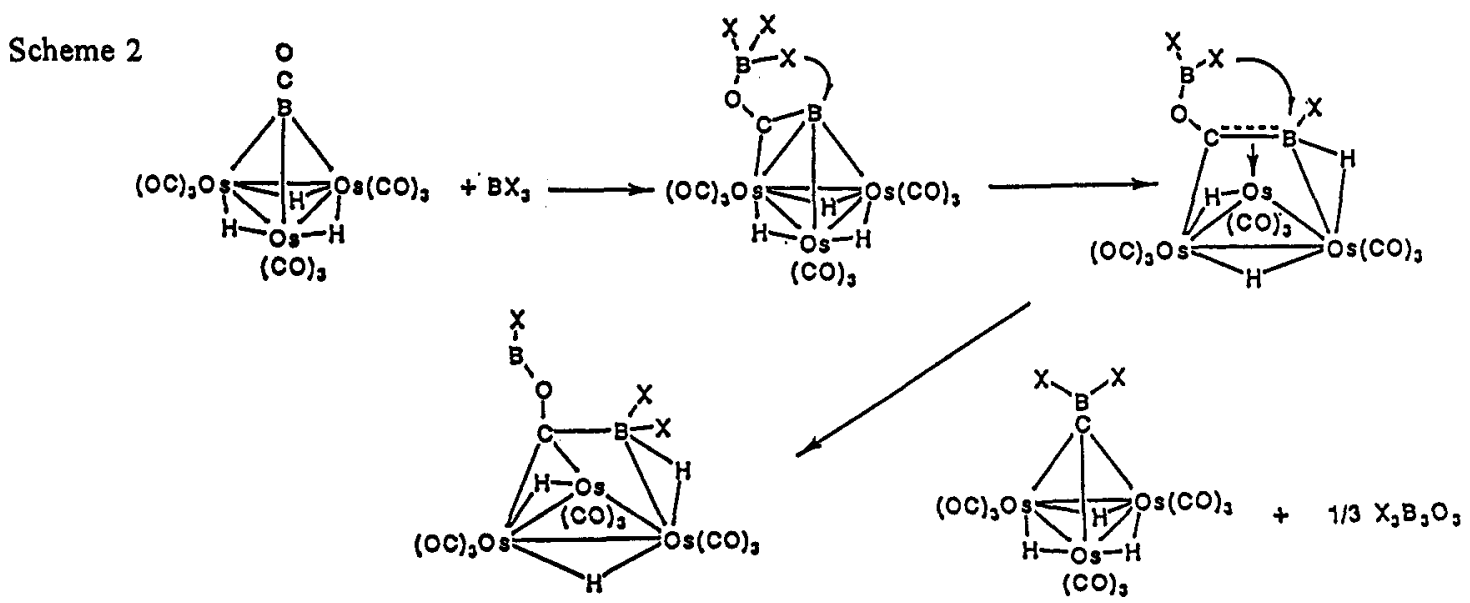


The tricoordinate boron in VIII can accept donor molecules to form Lewis acid-base adducts $(\mu-\mathrm{H})_{3} \mathrm{Os}_{3}(\mathrm{CO})_{9}\left(\mu_{3} \cdot \mathrm{CBCl}{ }_{2} \mathrm{~L}\right), \mathbf{X},\left(\mathrm{L}=\mathrm{NMe}_{3}, \mathrm{PMe}_{3}, \mathrm{PPh}_{3}\right)$ (Reaction (8)) (8b). However above $-10^{\circ} \mathrm{C}$

$$
\begin{aligned}
& -40{ }^{\circ} \mathrm{C} \\
& (\mu-\mathrm{H})_{3} \mathrm{Os}_{3}(\mathrm{CO})_{9}\left(\mu_{3}-\mathrm{CBCl}_{2}\right)+\mathrm{L} \longrightarrow(\mu-\mathrm{H})_{3} \mathrm{Os}_{3}(\mathrm{CO})_{9}\left(\mu_{3}-\mathrm{CBCl}_{2} \mathrm{~L}\right) \\
& \mathrm{L}=\mathrm{NMe}_{3}, \mathrm{PMe}_{3}, \mathrm{PPh}_{3}
\end{aligned}
$$

the trimethylene adduct is transformed to the salt $\left[\mathrm{NMe}_{3} \mathrm{H}\right]\left[(\mu-\mathrm{H})_{2} \mathrm{Os}_{3}(\mathrm{CO})_{9}\left(\mu_{3}-\mathrm{CBCl}_{2}\right)\right]$ through deprotonation of the cluster by the amine.

\section{B. Alkyne cluster analogues}

1. Reaction of I with $B-C I-9 B B N$ and $B P h C{ }_{2}$. An alkyne cluster analogue $(\mu-\mathrm{H})_{3} \mathrm{Os}_{3}(\mathrm{CO})_{9}\left[\mu_{3}-\right.$ $\left.\dot{\eta}^{2}-\mathrm{C}\left(\mathrm{OBC}_{8} \mathrm{H}_{14}\right) \mathrm{B}(\mathrm{Cl})\right], \mathbf{X}$, is formed from the reaction $\mathrm{I}$ with $B$-Cl-9BBN $\left(\mathrm{C}_{8} \mathrm{H}_{14} \mathrm{BCl}\right)$ (Reaction (9)) (8b, d). The structure of $X$ (Fig. 4a) reveals that in the formation of this compound the

$$
\left(\mu-\mathrm{H}_{3} \mathrm{Os}_{3}(\mathrm{CO})_{9}\left(\mu_{3}-\mathrm{BCO}\right)+\mathrm{C}_{8} \mathrm{H}_{14} \mathrm{BCl} \longrightarrow\left(\mu-\mathrm{H}_{3}\right)_{3} \mathrm{Os}_{3}(\mathrm{CO})_{9}\left[\mu_{3}-\hat{\eta}^{2}-\mathrm{C}\left(\mathrm{OBC}_{8} \mathrm{H}_{14}\right) \mathrm{B}(\mathrm{Cl})\right]\right.
$$

unique carbonyl of I moves to a $\mu_{3}$-site that caps two osmium atoms and the boron atom whereas the chlorine atom of the $B$-Cl-9BBN moves to the boron of the cluster. This compound is an alkyne cluster analogue in which a BH group takes the place of a carbon atom. The B-C bond is oriented nearly parallel (within $10^{\circ}$ ) to an Os-Os bond. It adopts the $\mu^{3}-\eta^{2}$ bonding mode that occurs for the C-C bond in alkyne cluster analogues (13). The bond distance is 1.46 (2) $\AA$, comparable to that in I, VII, and VIII and between the vaules for a B-C single bond, $c a 1.6 \AA(11 \mathrm{a}, \mathrm{b})$ and a B-C double bond, 1.361 (5) $\AA$, (11c).

Another alkyne cluster analogue $(\mu-\mathrm{H})_{3} \mathrm{Os}_{3}(\mathrm{CO})_{9}\left[\mu_{3}-\eta^{2}-\mathrm{C}\{\mathrm{OB}(\mathrm{Ph}) \mathrm{Cl}\} \mathrm{B}(\mathrm{Cl})\right], \mathrm{XI}$, is formed in the reaction of I with $\mathrm{BPhCl}_{2}$ (Reaction (10)) (8b). The proposed structure of XI (Fig. 4b) is related to that

$$
(\mu-\mathrm{H})_{3} \mathrm{Os}_{3}(\mathrm{CO})_{9}\left(\mu_{3}-\mathrm{BCO}\right)+\mathrm{BPhCl}_{2} \longrightarrow\left(\mu-\mathrm{H}_{3} \mathrm{Os}_{3}(\mathrm{CO})_{9}\left[\mu_{3}-\hat{\eta}^{2}-\mathrm{C}\{\mathrm{OB}(\mathrm{Ph}) \mathrm{Cl}\} \mathrm{B}(\mathrm{Cl})\right]\right.
$$

of $\mathbf{X}$ and is based upon spectroscopic data (IR, NMR).

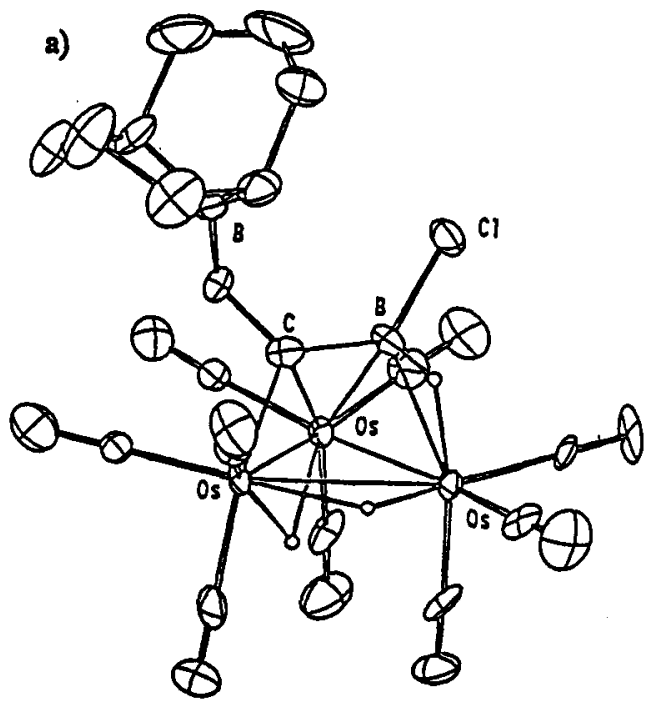

b)

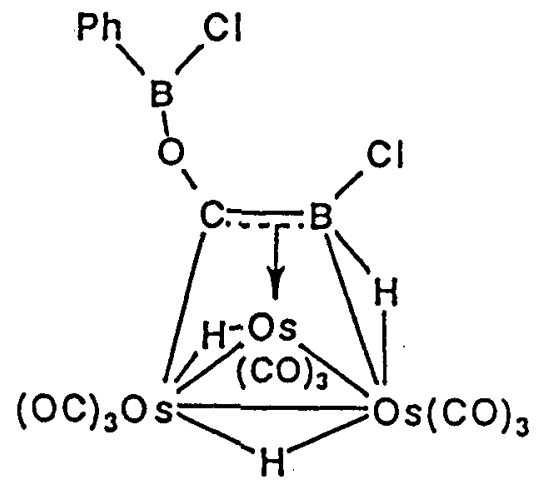

Fig. 4 a) Molecular structure of $\left(\mu-\mathrm{H}_{3} \mathrm{Os}_{3}(\mathrm{CO})_{9}\left[\mu_{3}-\hat{\eta}^{2}-\mathrm{C}\left(\mathrm{OBC}_{3} \mathrm{H}_{14}\right) \mathrm{B}(\mathrm{Cl})\right], \mathbf{X}\right.$.

b) Proposed structure of $\left(\mu-\mathrm{H}_{3} \mathrm{O} \mathrm{s}_{3}(\mathrm{CO})_{9}\left[\mu_{3}-\hat{\eta}^{2}-\mathrm{C}\{\mathrm{OB}(\mathrm{Ph}) \mathrm{Cl}\} \mathrm{B}(\mathrm{Cl})\right]\right.$, XI 
2. Reactions of $X$ and $X I$ with Boron Trihalides. Complexes $X$ and $X I$ are related to the proposed intermediate in Scheme 2 in the reaction of $\mathrm{I}$ with $\mathrm{BX}_{3}(\mathrm{X}=\mathrm{Cl}, \mathrm{Br})$. They react with boron trihalides to form compounds of type VIII, vinylidene cluster analogues (Reactions (11) and (12)) (8b).

$$
\begin{aligned}
& (\mu-\mathrm{H})_{3} \mathrm{Os}_{3}(\mathrm{CO})_{9}\left[\mu_{3}-\hat{\eta}^{2}-\mathrm{C}\left(\mathrm{OBC}_{3} \mathrm{H}_{14}\right) \mathrm{B}(\mathrm{Cl})\right]+\mathrm{BX}_{3} \longrightarrow \\
& \mathrm{X}=\mathrm{Cl}, \mathrm{Br} \quad(\mu-\mathrm{H})_{3} \mathrm{Os}_{3}(\mathrm{CO})_{9}\left(\mu_{3}-\mathrm{CBClX}\right)+1 / 3 \mathrm{~B}_{3} \mathrm{X}_{3} \mathrm{O}_{3}+B-\mathrm{X}-9 \mathrm{BBN} \\
& \left(\mu-\mathrm{H}_{3} \mathrm{Os}_{3}(\mathrm{CO})_{9}\left[\mu_{3}-\dot{\eta}^{2}-\mathrm{C}\{\mathrm{OB}(\mathrm{Ph}) \mathrm{Cl}\} \mathrm{B}(\mathrm{Cl})\right]+\mathrm{BCl}_{3} \longrightarrow\right. \\
& (\mu-\mathrm{H})_{3} \mathrm{Os}_{3}(\mathrm{CO})_{9}\left(\mu_{3}-\mathrm{CBCl}_{2}\right)+1 / 3 \mathrm{~B}_{3} \mathrm{Cl}_{3} \mathrm{O}_{3}+\mathrm{BPhCl}_{2}
\end{aligned}
$$

In scheme 2 the initial intermediate is an alkyne cluster analogue like $\mathbf{X}$ and $\mathbf{X I}$. In subsequent steps halogen is transferred to the boron atom of the cluster. In Reactions (11) and (12) the boron halide provides the additional halogen. A proposed sequence is given in Scheme 3.

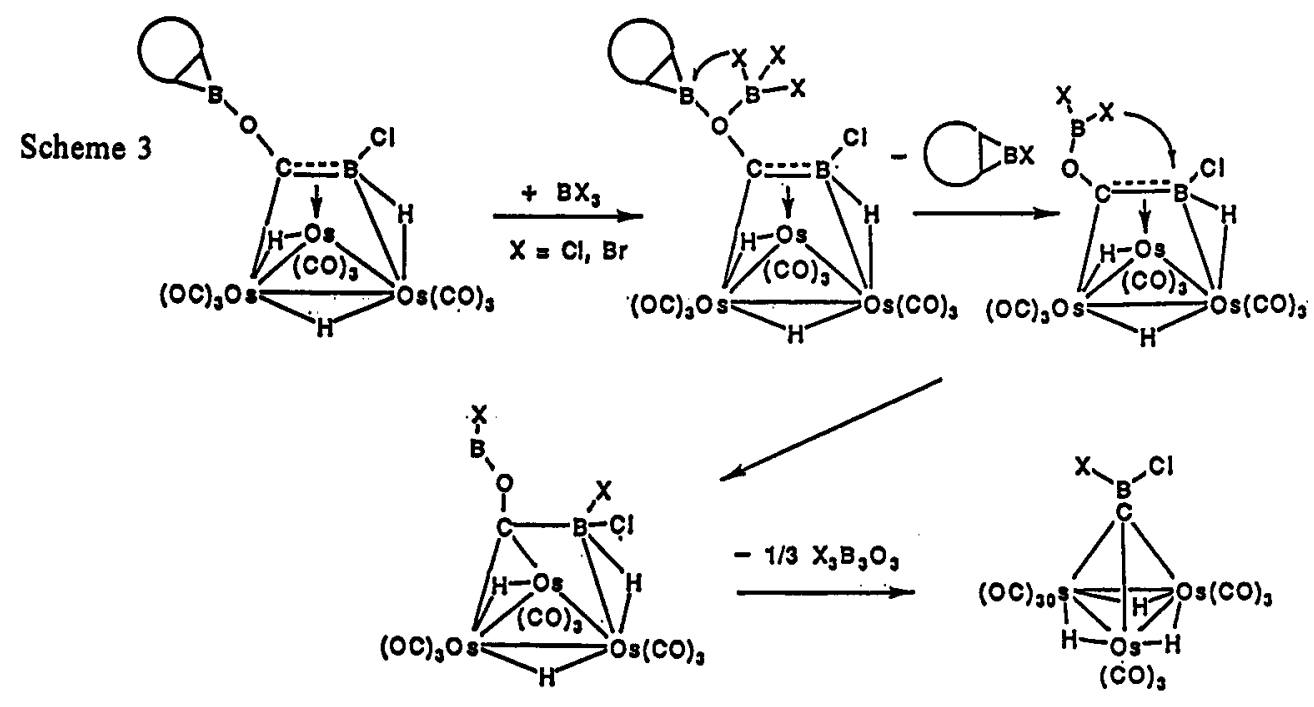

\section{FORMATION OF OSMABORIDE CLUSTERS FROM I}

The first examples of osmaboride clusters, $\mathrm{HOs}_{5}(\mathrm{CO})_{16} \mathrm{~B}, \mathrm{XII}$, and $\mathrm{HOs}_{4}(\mathrm{CO})_{12} \mathrm{BH}_{2}, \mathrm{Xm}$, were produced through the thermolysis of $I$ at $110^{\circ}$ (15a). In the structure of XII (Fig. 5a) the five Os atoms

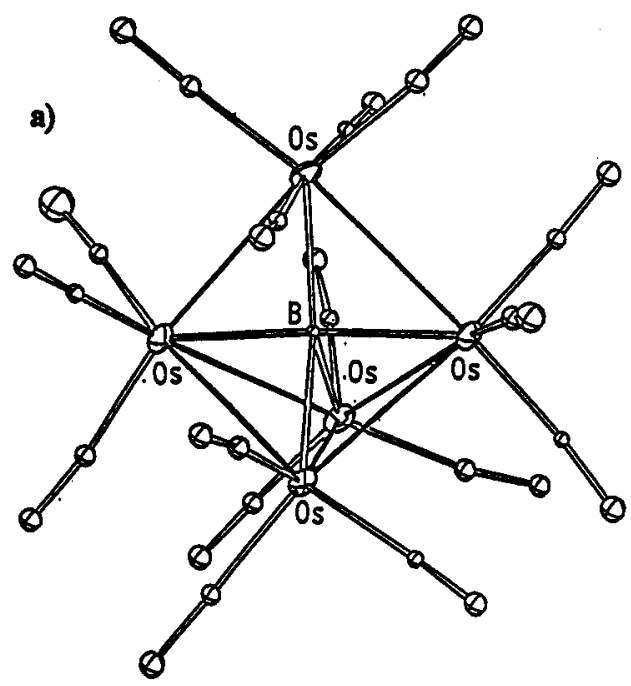

b)

Fig. 5 a) Molecular structure of $\mathrm{HOs}_{5}(\mathrm{CO})_{16} \mathrm{~B}, \mathrm{XII}$

b) Molecular structure of $\mathrm{HOs}_{4}(\mathrm{CO})_{12} \mathrm{BH}_{2}, \mathrm{XIII}$ 
define a bridged "butterfly" metal framework and the boron atom is encapsulated in the cluster, bonded to all five osmium atoms. The hydrogen atom was not located, but it is believed to be on the cluster surface, possibly bridging the two osmium atoms that form the hinge of the "butterfly". The overall molecular geometry of this cluster resembles the pentaosmium carbonyl carbide cluster $\mathrm{Os}_{5}(\mathrm{CO})_{16} \mathrm{C}(14 \mathrm{~b})$ containing a carbon atom encapsulated in the $\mathrm{Os}_{5}$ core. Complex XII like $\mathrm{Os}_{5}(\mathrm{CO}) \mathrm{C}$ is a 76 valence electron system. From the Wade, Williams, and Rudolph electron counting rules (15 a, b, c), this compound can be considered to be an arachno cluster that is derived from a pentagonal bipyramid from which non-adjacent equatorial vertices are removed.

The molecular structure of XII (Fig. Sb) contains four Os atoms forming a "butterfly" cluster core with the boron atom residing midway between the osmium atoms that define the wing tips. This molecule is isostructural with ruthenium (16a) and iron (16b) analogues and is considered to be an arachno, four atom cluster with an interstitial boron or alternatively a 62 valence electron complex in which the $\mathrm{BH}_{2}$ ligand contributes five electrons on the basis of the skeletal electron-pair theory (15a). Although the bridging hydrogens were not located from the X-ray data, ${ }^{11} B$ and ${ }^{1} H$ NMR spectra indicate that they are located at the positions shown in Fig. 5b. Complex XIII is deprotonated by $\mathrm{KH}$ in ether solvents (Reactions (13) and (14)) (14a). In these reactions, deprotonation occurs at the Os-H-B bridges, which is

$$
\begin{aligned}
& \mathrm{HOs}_{4}(\mathrm{CO})_{12} \mathrm{BH}_{2}+\mathrm{KH} \longrightarrow \mathrm{K}\left[\mathrm{HOs}_{4}(\mathrm{CO})_{12} \mathrm{BH}\right]+\mathrm{H}_{2} \\
& \mathrm{~K}\left[\mathrm{HOs}_{4}(\mathrm{CO})_{12} \mathrm{BH}\right]+\mathrm{KH} \longrightarrow \mathrm{K}_{2}\left[\mathrm{HO}_{4}(\mathrm{CO})_{12} \mathrm{~B}\right]+\mathrm{H}_{2}
\end{aligned}
$$

consistent with results from deprotonation studies of $\mathrm{HRu}_{4}(\mathrm{CO})_{12} \mathrm{BH}_{2}(16 \mathrm{a})$ and confirms, further, the predictions of Fehlner (17) concerning the deprotonation of these clusters.

\section{TRIOSMIUM METHYLIDYNE CLUSTER DERIVATIVES OF III}

\section{A. Reactions with boron trihalides}

The boroxin supported triosmium oxomethylidyne cluster, III, (Figure 2a) is a useful reagent in the preparation of methylidyne cluster derivatives. Boron trichloride and boron tribromide react with III to produce triosmium chloro and bromomethylidyne clusters, $(\mu-\mathrm{H})_{3} \mathrm{Os}_{3}(\mathrm{CO})_{9}\left(\mu_{3}-\mathrm{CX}\right)(\mathrm{X}=\mathrm{Cl}, \mathrm{Br}), \mathrm{XIV}$, (Reaction (15)) (2a, 8b). In this reaction it is believed that the boron halide coordinates to the oxygen atom

$$
\begin{aligned}
& {\left[(\mu-\mathrm{H})_{3} \mathrm{Os}_{3}(\mathrm{CO})_{9}\left(\mu_{3}-\mathrm{CO}\right)\right]_{3}\left[\mathrm{~B}_{3} \mathrm{O}_{3}\right]+3 \mathrm{BX}_{3}-3(\mu-\mathrm{H})_{3} \mathrm{Os}_{3}(\mathrm{CO})_{9}\left(\mu_{3}-\mathrm{CX}\right)} \\
& \quad \mathrm{X}=\mathrm{Cl}, \mathrm{Br}
\end{aligned}
$$

of the C-O-B unit followed by transfer of a halogen atom to the methylidyne carbon atom with rupture of the carbon-oxygen bond $(2 a, 8 b)$, as indicated in Scheme $4 a$.

\section{Scheme 4}
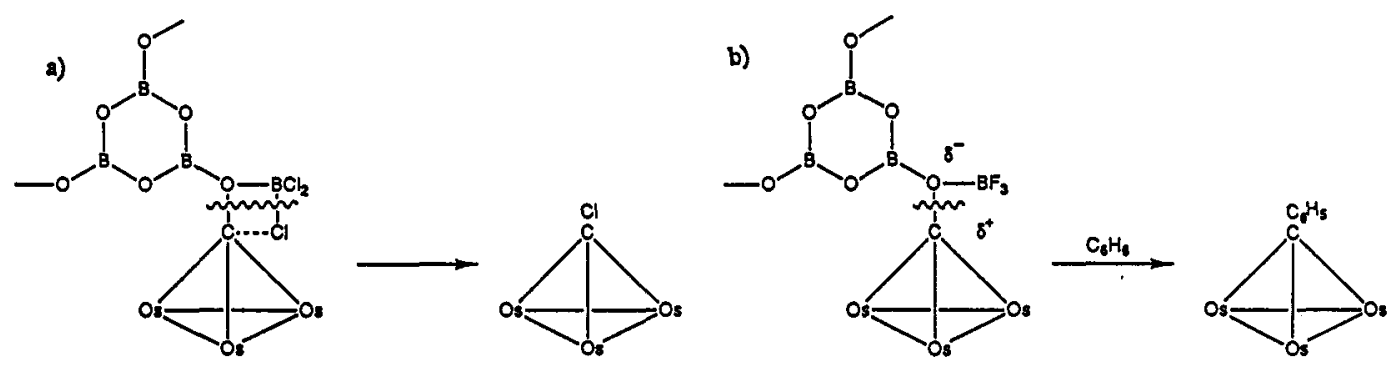

Complex IV contains a C-O-B bond (Fig. 2b) and it also reacts with $\mathrm{BBr}_{3}$ to form XIV (Reaction 16) (8b).

$$
\left.(\mu-\mathrm{H})_{3} \mathrm{Os}_{3} \mathrm{CO}\right)_{9}\left(\mu_{3}-\mathrm{COBO}_{2} \mathrm{C}_{6} \mathrm{H}_{4}\right)+\mathrm{BBr}_{3} \longrightarrow 3(\mu-\mathrm{H})_{3} \mathrm{Os}_{3}(\mathrm{CO})_{9}\left(\mu_{3}-\mathrm{CBr}\right)
$$


Boron trifluoride reacts with III in $\mathrm{CH}_{2} \mathrm{Cl}_{2}$ to give an uncharacterized highly air and moisturesensitive product. However, when the reaction is undertaken in benzene, the triosmium phenylmethylidyne cluster $(\mu-\mathrm{H})_{3} \mathrm{Os}_{3}(\mathrm{CO})_{9}\left(\mu_{3}-\mathrm{CPh}\right), \mathbf{X V}$, is produced (Reaction (17)) (2a, 8b). As in Reactions (15) and (16),

$$
\left[(\mu-\mathrm{H})_{3} \mathrm{Os}_{3}(\mathrm{CO})_{9}\left(\mu_{3}-\mathrm{CO}\right)\right]_{3}\left[\mathrm{~B}_{3} \mathrm{O}_{3}\right]+\mathrm{C}_{6} \mathrm{H}_{6} \stackrel{\mathrm{BF}_{3}}{\longrightarrow} 3(\mu-\mathrm{H})_{3} \mathrm{Os}_{3}(\mathrm{CO})_{9}\left(\mu_{3}-\mathrm{CX}\right)
$$

the boron trihalide is believed to coordinate to the methylidyne oxygen. But in this case unlike the $\mathrm{BCl}_{3}$ and $\mathrm{BBr}_{3}$ adducts, fluorine is not transferred to the methylidyne carbon. Instead, either hetrolytic cleavage of the $\mathrm{C}-\mathrm{O}$ bond to produce a triosmium methylidyne carbonium ion or perhaps extreme polarization of the $\mathrm{C}-\mathrm{O}$ bond occurs as indicated in Scheme $4 \mathrm{~b}$ to form an intermediate capable of electrophilic attack of the benzene solvent (19), thereby facilitating a Friedel-Crafts type of Reaction (18).

\section{B. "Alkylation" of pentaborane(9) and 1,2- $\mathrm{C}_{2} \mathrm{~B}_{10} \mathrm{H}_{12}$}

That several boron hydrides (20) and carboranes (21) undergo Friedel Crafts type reactions resulting in electrophilic displacement of a B-H hydrogen, prompted attempts to link a borane or a carborane cage to a triosmium methylidyne unit through the formation of a B-C bond (19). In the presence of $\mathrm{BF}_{3}$ pentaborane $(9)$ reacts with III to produce $(\mu-\mathrm{H})_{3} \mathrm{Os}_{3}(\mathrm{CO})_{9}\left(\mu_{3}-\mathrm{CB}_{5} \mathrm{H}_{8}\right)$, XVI, (Reaction (18) (22). The

$$
\left[\left(\mu-\mathrm{H}_{3} \mathrm{Os}_{3}(\mathrm{CO})_{9}\left(\mu_{3}-\mathrm{CO}\right)\right]_{3}\left[\mathrm{~B}_{3} \mathrm{O}_{3}\right]+\mathrm{B}_{5} \mathrm{H}_{9} \stackrel{\mathrm{BF}_{3}}{\longrightarrow} 3\left(\mu-\mathrm{H}_{3} \mathrm{O}_{3}(\mathrm{CO})_{9}\left(\mu_{3}-\mathrm{CB}_{5} \mathrm{H}_{8}\right)\right.\right.
$$

proposed structure of XVI (Fig. 6a) is readily deduced from NMR and mass spectra. The pentaborane(9) is substituted at the apex which is consistent with other examples of electrophilic substitution of this molecule (20) and supports a Friedel-Crafts type reaction where electrophilic attack is expected at the most negative boron atom $(20 \mathrm{e})$, the apical atom of $\mathrm{B}_{5} \mathrm{H}_{9}$.

In the presence of $\mathrm{BF}_{3} 1,2-\mathrm{C}_{2} \mathrm{~B}_{10} \mathrm{H}_{10}$ reacts with III to produce $(\mu-\mathrm{H})_{3} \mathrm{Os}_{3}(\mathrm{CO})_{9}\left(\mu_{3}-\mathrm{C}\left\{\mathrm{C}_{2} \mathrm{~B}_{10} \mathrm{H}_{10}\right\}\right)$, XVII (Reaction (19)) (22). The proposed structure for XVII (Fig. 6b) is based on the observation

$$
\left[(\mu-\mathrm{H})_{3} \mathrm{Os}_{3}(\mathrm{CO})_{9}\left(\mu_{3}-\mathrm{CO}\right)\right]_{3}\left[\mathrm{~B}_{3} \mathrm{O}_{3}\right]+1,2-\mathrm{C}_{2} \mathrm{~B}_{10} \mathrm{H}_{12} \stackrel{\mathrm{BF}_{3}}{\longrightarrow} 3\left(\mu-\mathrm{H}_{3} \mathrm{Os}_{3}(\mathrm{CO})_{9}\left(\mu_{3}-\mathrm{C}\left\{\mathrm{C}_{2} \mathrm{~B}_{10} \mathrm{H}_{10}\right\}\right)\right.
$$

that electrophilic substitution occurs predominantly at the boron atom farthest from the carbons of the carborane structure (21).

a)

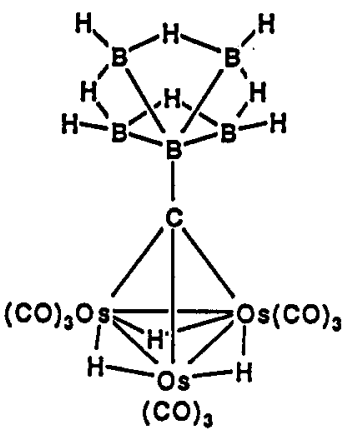

b)

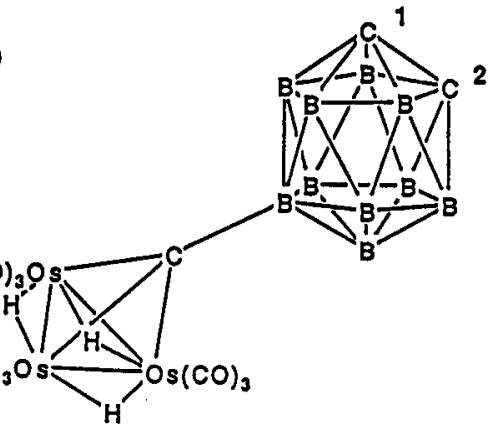

Fig. 6 a) Proposed structure of $(\mu-\mathrm{H})_{3} \mathrm{Os}_{3}(\mathrm{CO})_{9}\left(\mu_{3}-\mathrm{CB}_{5} \mathrm{H}_{8}\right)$.

b) Proposed structure of $(\mu-\mathrm{H})_{3} \mathrm{Os}_{3}(\mathrm{CO})_{9}\left(\mu_{3}-\mathrm{C}\left(\mathrm{C}_{2} \mathrm{~B}_{10} \mathrm{H}_{10}\right)\right.$.

\section{Acknowledgement}

This work was supported by the National Science Foundation. 


\section{REFERENCES}

1. H. C. Brown. Acc. Chem. Res. 2, 65 (1969).

2. a) S. G. Shore, D.-Y. Jan, L.-Y. Hsu, and W.-L. Hsu. J. Am. Chem. Soc. 105, 5923(1983). b) S. G. Shore, D.-Y. Jan, W.-L. Hsu, S. Kennedy, J. Hoffman, T.-C. Lain Wang, and A. G. Marshall. J. Chem. Soc., Chem. Comm. 392 (1984). c) D.-Y. Jan, D. P. Workman, L.-Y. Hsu, J. A. Krause, and S. G. Shore. Inorg. Chem.31, 5123 (1992).

3. a) G. A. Carriendo, G. P. Elliott, J. A. K. Howard, D. B. Lewis, and F. G. A. Stone. J. Chem. Soc., Chem. Comm. 1585 (1984). b) D. Barratt, S. J. Davies, G. P. Elliott, J. A. K. Howard, and F. G.

A. Stone. J. Organomet. Chem. 325, 105 (1987).

4. D.-Y. Jan. Ph. D. Dissertation, The Ohio State University, 1985.

5. a) C. Y. Chang, C. E. Johnson, T. G. Richmond, Y. T. Chen, W. C. Trogler, and F. Basolo. Inor. Chem. 20, 3137 (1981). b) Q.-Z. Shi, T. G. Richmond, W. C. Trogler, and F. Basolo. J. Am. Chem. Soc. 106, 71 (1984).

6. D. C. Sonneberger, J. D. Atwood. Inorg. Chem. 20, 3243 (1981).

7. a) G. Hutter, J. Schneider, H.-D. Muller, G. Mohr, J. von Seyerl, and L. Wohlfahrt. Angew. Chem. Int. Ed. Engl. 18, 76 (1979). b) L. J. Farrugia, J. A. K. Howard, P. Mitroprachachon, J. L. Spencer, F. G. A. Stone, and P. Woodward. J. Chem. Soc., Chem. Commun. 260 (1978). c) L. J. Farrugia, M. Green, D. R. Hankey, A. G. Orpen, and F. G. A. Stone. J. Chem. Soc., Chem. Commun. 310 (1983).

8. a) D.-Y. Jan and S. G. Shore. Organometallics 6, 428 (1987). b) D. P. Workman, D.-Y. Jan, and S. G. Shore. Inorg. Chem. 29, 3518 (1990). c) D.-Y. Jan, L.-Y. Hsu, D. P. Workman, and S. G. Shore. Organometallics. 6, 1984 (1987). d) Workman, D. P, H.-B. Deng, and S. G. Shore. Angew. Chemie, Int. Ed. Engl. 29, 3518 (1990).

9. a) A. J. Deeming and M. Underhill. J. Chem. Soc., Chem. Commun. 277 (1973). b) A. J. Deeming and M. Underhill. J. Chem. Soc., Dalton Trans. 1415 (1974).

10. a) R. Dodsworth, T. Dutton, B. F. G. Johnson, J. Lewis, and P. R. Raithby. A cta Crystallogr. C45, 707 (1989). b) A. A. Aradi, F. W. Grevels, C. Krueger, E. Raabe. Organometallics 7, 812 (1988). c) D. Seyferth, J. B. Hoke, M. Cowie, and A. D. Hunter. J. Organomet. Chem. 346, 91 (1988). d) T. Albietz, W. Bernhardt, C. von Schnering, E. Roland, H. Bantel, and H. Vahrenkamp. Chem. Ber. 120, 141 (1987). e) Roland, E., B. Wolfgang, and H. Vahrenkamp. ibid. 118, 2858 (1985).

11. a) D. J. Saturnino, M. Yamauchi, W. R. Clayton, W. R. Nelson, and S. G. Shore. J. A m. Chem. Soc. 97, 6063 (1975). b) L.-Y. Hsu, J. F. Marategui, K. Niedenzu, and S. G. Shore. Inorg. Chem. 26, 143 (1987). c) R. Boese, P. Paetzold, A. Tapper, and R. Ziembinski. Chem. Ber. 122, 1057 (1989)

12. A. Fratiello, T. P. Onak, and R. E. Schuster. J. Am. Chem. Soc. 90, 1194 (1968).

13. a) E. Sappa, A. Tripicchio, and P. Braunstein. Chem. Rev. 83, 203 (1983) and references therein. b) P. R. Raithby, and M. J. Rosales. J. Adv. Inorg. Chem. Radiochem. 29, 169 (1985).

14. a) J. H. Chung, D. Knoeppel, D. McCarthy, A. Columbie, and S. G. Shore. Inorg. Chem. 32, 3391 (1993). b) B. F. G. Johnson, J. Lewis, W. J. H. Nelson, J. N. Nicholls, J. Puga, P. R. Raithby, M. J. Rosales, M. Schroder, and M. D. Vargas. J. Chem. Soc. Dalton Trans. 2447 (1983).

15. a) K. Wade. Adv. Inorg. Chem. Radiochem. 18, 1 (1976). b) R. E. Williams. Inorg Chem. 10, 210 (1971). c) Rudolph, R. W. and W. R. Pretzer. Inorg. Chem. 11, 1974 (1972).

16. a) F.-E. Hong, D. A. McCarthy, J. P. White, III, C. E. Cottrell, and S. G. Shore. Inorg. Chem. 28 , 3284 (1990). b) K. S. Wong, W. R. Scheidt, T. P. Fehlner. J. Am. Chem. Soc. 104, 1111 (1982). c) T. P. Fehlner, C.E. Housecroft, W. R. Scheidt, K. S. Wong. Organometallics. 7, 2302 (1983).

17. T. P. Fehlner. Polyhedron 9, 1955 (1990).

18. a) J. B. Kiester. J. Chem. Soc, Chem. Commun. 214 (1979). b) J. B. Kiester and T. Horling. Inorg. Chem. 19, 2304 (1980). c) J. B. Kiester, M. W. Payne, and M. J. Muscatella. Organometallics 2, 219 (1983).

19. a) R. Dolby and B. H. Robinson. J. Chem. Soc. Dalton Trans. 2046 (1972). b) D. Seyferth, J. E. Hallgren, C. S. Eschbach. J. Am. Chem. Soc. 96, 1730 (1974).

20. a) N. J. Blay, I. Dunstan, and R. L. Williams. J. Chem. Soc. 430 (1960). b) G. E. Ryschkewitsch, S. W. Harris, E. J. Mezey, H. H. Sisler, E. A. Weilmuenster, and A. B. Garrett. Inorg. Chem. 2, 890 (1963). c) J. A. Dupont and M. F. Hawthorne. J. Am. Chem. Soc. 84, 1804 (1962). d) D. Gaines and J. A. Martens. Inorg. Chem. 7, 704 (1968). e) W. N. Lipscomb. Boron Hydrides Wm. Benjamin, New York, pp. 171-180 (1965).

21. L. I. Zakharkin, V. I. Kalinin, and V. S. Lozovskaya Bull. Acad. Sci. Ussr, Div. Chem. Sci. (Engl. Transl.) 1683 (1968).

22. J. R. Wermer, D. -Y. Jan, T. D. Getman, E. Mohrer, and S. G. Shore. Inorg. Chem. 27, 4274 (1988). 